\title{
Urban Diabetic Women's Perception of Healthy Eating Lifestyles from West Java
}

\author{
Mayumi Mizutani $^{1}$, Junko Tashiro ${ }^{2}$, Nia Damiati ${ }^{3}$, Uswatun Khasanah ${ }^{3}$ \\ ${ }^{1}$ Doctoral Program, St. Luke's International University, Tokyo, Japan, ${ }^{2}$ Global Health Nursing, St. \\ Luke's International University, Tokyo, Japan, ${ }^{3}$ Faculty of Medicine and Health Science, Syarif \\ Hidayatullah State Islamic University Jakarta \\ E-mail: 12dn0101u5q-ts@slcn.ac.jp
}

\begin{abstract}
This study aimed to explore perceptions about a healthy-eating lifestyle and reasons to practice a healthy-eating lifestyle of women with type 2 diabetes in a city of West Java by using a case study design. Six female patients, with type 2 diabetes, ages 47-63 from a hospital were interviewed guided by the health promotion model. Their healthyeating lifestyle included currently practicing or not practicing a healthy-eating lifestyle. Reasons to practice were: beliefs for health and for physical energy to work for family, definition of multidimensional health and self-efficacy increased by: support from God, support from family, support from health professionals and improved or deteriorated health status by prior experience. Reasons not to practice were: difficulty in arranging diet, rejecting eating, controlling appetite, and accessing health care services. Related difficulties were interpersonal relations with family and social situation such as social events, expensive medical fee, and distance to the hospital. These findings suggest that women with type 2 diabetes in Indonesia need to be supported with the reasons to practice a healthy-eating lifestyle.
\end{abstract}

Key words: Diet, health promotion, Indonesia, type 2 diabetes, women.

\section{Persepsi Wanita Perkotaan Penderita Diabetes tentang Gaya Hidup Memakan Makanan Sehat dari Jawa Barat}

\begin{abstract}
Abstrak
Tujuan dari penelitian ini adalah untuk mengeksplorasi persepsi tentang gaya hidup mengonsumsi makanan sehat dan alasan untuk mempraktikkan gaya hidup memakan makanan sehat pada wanita penderita diabetes tipe 2 di satu kota di Jawa Barat dengan menggunakan desain penelitian studi kasus. Enam pasien wanita penderita diabetes tipe 2 berumur antara 47-63 tahun. Penelitian ini dilakukan di sebuah rumah sakit. Pasien diwawancara secara terbimbing menggunakan model promosi kesehatan. Gaya hidup partisipan dalam mengonsumsi makanan sehat dinilai dalam penelitian ini, termasuk yang sedang dipraktikkan atau tidak sedang dipraktikkan. Hasil penelitian menunjukkan alasan partisipan untuk mengonsumsi makanan sehat adalah: keyakinan untuk sehat dan kekuatan fisik untuk bekerja bagi keluarga, definisi kesehatan multidimensi dan efikasi diri meningkat oleh dukungan Tuhan, dukungan dari keluarga, dukungan dari petugas kesehatan, dan meningkatnya atau menurunnya status kesehatan oleh pengalaman sebelumnya. Alasan untuk tidak mengonsumsi makanan sehat adalah kesulitan dalam: mengatur diet, menolak makan, mengontrol nafsu makan, dan kesulitan mengakses pelayanan kesehatan. Kesulitan-kesulitan yang terkait dengan masalah ini adalah hubungan interpersonal dengan keluarga dan situasi sosial seperti acaraacara sosial, biaya medis yang mahal, dan jarak ke rumah sakit. Penelitian ini menyarankan peningkatan dukungan bagi wanita penderita diabetes tipe 2 di Indonesia agar mempraktikkan gaya hidup memakan makanan yang sehat.
\end{abstract}

Kata kunci: Diabetes tipe 2, Indonesia, makanan, promosi kesehatan, wanita. 
Mayumi Mizutani: Urban Diabetic Women's Perception of Healthy Eating Lifestyles

\section{Introduction}

Like other middle-income in countries, Indonesia is suffering from a double burden of communicable and noncommunicable diseases (NCDs). Globally, NCDs have a substantial contribution to morbidity and mortality, which are responsible for $63 \%$ of all deaths worldwide (World Health Organization [WHO], 2011). In Indonesia, NCDs such as stroke, hypertension, and diabetes (Departemen Kesehatan Republik Indonesia, 2009), account for 64\% of all deaths (WHO, 2011b). It is especially, noteworthy that the number of people with type 2 diabetes in Indonesia is estimated to increase $253 \%$ from 8.4 million in 2000 to 21.3 million in 2030 (Wild, 2004).

Unhealthy diet and physical inactivity are the leading causes of the major NCDs (WHO, 2004). Globalization and urbanization are the underlying factors of NCDs (WHO, 2005). Nutrition transition, the consumption of diets high in total fats and sugar, resulting from the economic forces of globalization created rising rates of diet-related chronic diseases including diabetes (Hawkes, 2006). Furthermore, urbanization creates conditions in which people tend to adopt less physical activity (Brown, 2001).

There are an increasing number of nutritional-related diseases (cardiovascular [hypertension] disease, type 2 diabetes, and obesity) in Indonesia (Departemen Kesehatan Republik Indonesia, 2009). The majority of the studies about type 2 diabetes in Indonesia are large-scale epidemiological studies that acknowledge the necessity for lifestyle change and diet however the focus of these studies is mainly about medical management in other words pharmacological control, especially given the lack of control of the majority of the study group (Soewondo, et al., 2010). However, the impact of globalization and urbanization factors influencing a healthy diet as a part of one's lifestyle has received scant attention (Brown, 2001). Dewi (2010) found that in Java, women were perceived as the family caretakers for health in addition to domestic tasks and employment. Therefore, a life-course perspective (WHO, 2004), which encourages a healthy diet and regular physical activity from youth into old age and which is essential for people under the age of 60 (WHO, 2005) places a great responsibility on women in Indonesia.

In order to explore nursing approaches for promoting Indonesian women's healthyeating lifestyle, it was important to understand their perceptions about healthyeating lifestyles and reasons to practice a healthy-eating lifestyle within their cultural context. However, there was limited research focusing on diabetes (Soewondo, et al., 2010; Nordisk, 2013), in particular on their eating lifestyle from the perspective of health promotion.

In order to understand women's lifestyle in terms of these complexities multidimensional models were needed. Therefore we used Bandura's social cognitive theory (SCT) (1986), describing human behavior as the product of the dynamic interplay of personal, behavioral, and environmental influences. Because of the multiplicity of interacting influences, the same factor can be a part of different blends of conditions that have different effects. In addition, we drew on Pender who used SCT and expectancy-theory as foundational concepts in developing the Health Promotion Model (HPM) in the 1980s (Ho, Berggren, \& DahlborgLyckhage, 2010). The HPM attempts to depict the multidimensional nature of persons interacting with their interpersonal and physical environments as they pursue health (Pender, Murdaugh, \& Parsons, 2011). These two models informed the conceptualization of our inquiry into the lifestyle of women with type 2 diabetes and the forces impinging on their healthy eating.

The purpose of this study was to describe the perceptions that women, in an urban area of West Java, with type 2 diabetes had about their healthy-eating lifestyle and their reasons to practice a healthy-eating lifestyle in order to explore effective nursing approaches that might enhance their healthy-eating lifestyle.

\section{Methods}

The design used in this study was a descriptive case study (Yin, 2008) because little is known about the women's perception's of their healthy eating lifestyles. Yin's case study 
Mayumi Mizutani: Urban Diabetic Women's Perception of Healthy Eating Lifestyles

design provides for a complete systematic description of a phenomenon within its context.

The study field was a referral hospital in a city of West Java. The city was the third largest city in Indonesia with its population of 2.4 million (Pemerintah Kota Bandung, 2010). The majority of people in the city were within the working-age group (15-64 years) $(72 \%)$. Consistent with the nation, the majority of the population (97\%) was Muslim (Badan Pusat Statistik Kabupaten Bandung, 2009). In the city, the life expectancy was 73 years and DMT2 was ranked in the top 10 for morbidity among age group 45-64 years. Health insurance coverage in the city was only 28\% (Dinas Kesehatan Provinsi Jawa Barat, 2008).

The city had been experiencing economic growth and urbanization commiserate with Indonesiaincluding thelifestylechanges(Rada \& Regmi, 2010). Due to the urbanization, traditional markets operated along with modern supermarkets and fast-food stores and were accessible in the centre of the city. Increasingly, people are purchasing packaged products rather than purchasing unprocessed products from traditional markets (Rada \& Regmi, 2010). Greater food consumption and increased purchasing power have contributed to an average Indonesian per capita food availability (Rada \& Regmi, 2010) growing from 1,743 kilocalories per capita per day in 1961 to 2,583 kilocalories in 2007, a 48\% increase (Food and Agriculture Organization of the United Nations, 2010).

The researchers purposively recruited six patients who had been hospitalized or who came to the hospital for their monthly medical check-up. Inclusion criteria were: women aged 40-64 years with a confirmed diagnosis of type 2 diabetes, not pregnant, and willing to participate.

The data were collected from semistructured interviews and medical records in July 2011. Each interview was conducted in the official language of Bahasa Indonesia. The researchers used an interview guide, which was based on the SCT, literature that used the SCT (Early, Shultz, \& Corbett., 2009; Hjelm, Bard, Nyberg, \& Apelqvist, 2003; McCloskey \& Flenniken, 2010), and the HPM. The following questions were used as the initial prompts for the semi-structured interviews: Do you feel healthy now?, Why do you feel so?, What does good health mean to you?, What does healthy-eating lifestyle mean to you?, Is there any change in your eating lifestyle since you got diabetes?, What or who helps or encourages you to practice a healthy-eating lifestyle?, and What hinders or prevents you from practicing a healthyeating lifestyle?. The data was written on field notes, audio-recorded, and transcribed. Each interview lasted 73 minutes on average.

Based on Yin's (2008) analytic technique's for case studies, the data was analyzed to stipulate a presumed set of causal links for example "how" or "why" something happened" to "explain" a phenomenon. The process was: 1) describe perceived healthyeating lifestyle; 2) describe perceived reasons to practice a healthy-eating lifestyle; and 3) these findings were synthesized and compared to the HPM and existing literature.

This study included the following: voluntary participation, privacy protection, and data security. Before beginning data collection, the researchers explained the purpose and the process of the study to the participants and their written informed consent was obtained. The data that they provided were recorded with the participants' consent and were treated anonymously. The researchers explained that the results of the study might be published, but participants' anonymity would be protected. Audio data and interview transcripts were securely stored in a locked place. All data will be destroyed three years after the study completion. The hospital board granted permission to conduct the study. The research ethics committee of St. Luke's College of Nursing, Japan approved the study.

\section{Results}

Participants characteristics

The mean age was 53.8. Of the six participants two were hospitalized at the time of interview. Participants completed either: primary school, junior high school, senior high school, or a diploma course. Five were married. One was widowed. Regarding their role at home, three were 'both homemaker and taking care of family' and three were 
one or the other. Four prepared meals by themselves. Their religious affiliations were as follows: four were Muslim and two were Christian. When asked about things they like to do during free time, three listed religious activity like 'pengajian' (muslim gathering to recite the Qur'an) and church activities for Christians. The average distance from the participant's house to the hospital was 39 minutes. Regarding the possession of health insurance, three had insurance.

A model of reasons to practice a healthyeating lifestyle for women with DMT2 in a city of West Java. The first category was 'perceived healthy-eating lifestyle' with two subcategories. The second category was 'perceived reasons for healthy-eating lifestyle' with ten subcategories. A model of reasons to practice a healthy-eating lifestyle for women with type 2 diabetes in a city of West Java was derived from a synthesis of the findings. Following are the categories and subcategories.

Perceived healthy-eating lifestyle

The patterns of eating making up their eating-lifestyle included regularity of meals, amount consumed, types of food consumed, and cleanliness. While all participants had made some changes in eating lifestyle after their diagnosis of DMT2, three of them failed to make all the necessary changes in eating lifestyle. Supporting indicators are detailed for the following two subcategories 'healthyeating lifestyle currently practicing' and healthy-eating lifestyle not practicing'.

Healthy-eating lifestyle currently practicing (a) Regular frequency of meals. This meant taking meals three times a day at regular times in the morning, afternoon, and evening. "I ate if I wanted to. Recently I already knew that I got diabetes, I eat regularly three times a day." (b) Amount of consumption reduced. This meant that participants reduced the amount of consumption of food like sugar and fat intake. "There is a change about the amount of consumption after the diagnosis. Although I like ice cream, I reduced sweets for health. I do not use sugar but I use sweetening. Considering my condition (high cholesterol), I remove fat from meat (when cooking)." (c) Diet should contain vegetables, fruits, and protein. One participant explained, 'Four healthy five completely' was national nutritional slogan to eat carbohydrate, protein and fat, vegetables, fruits, plus milk.

(d) Cleanliness for self and food. In other words, participants kept food in a refrigerator; washed their hands and the food before cooking in order to keep them clean.

Healthy-eating lifestyle not practicing Do not follow recommended content of diet. Not all participants were able or willing to follow their diets. One reported that she usually ate snacks instead of eating lunch. Another reported that she did not eat meat because of her preference. A participant said that although she knew about the common saying, "four healthy five completely" she did not follow it due to her food preference. "Four healthy five completely', it is good but I do not follow because I do not like it."

Perceived reasons to practice a healthy-eating lifestyle

Participants practiced a healthy-eating lifestyle for the following reasons presented as seven subcategories: beliefs, definition of multidimensional health, self-efficacy, improved or deteriorated health status by prior eating lifestyle, support from God, support from family, and support from trusted health professionals. However, they were not able to practice a healthy-eating lifestyle due to the following reasons presented as three subcategories: difficulties, interpersonal relations, and social situation.

Beliefs about healthy-eating lifestyle

Two participants stated they practiced healthy eating lifestyle "for health", and two stated "for physical energy to work for my family". For health was practicing a healthy-eating lifestyle because they knew they had DMT2 and wanted to be healthy. For physical energy to work for my family indicated they engaged in a healthy-eating lifestyle so they would have enough physical energy to work for their family. "In order for the body to have energy. I do not have a housemaid at home, so I have to do everything by myself. I totally prepared the food, like buying food, preparing the food, serving the food, and washing the dishes. That's why I 
Mayumi Mizutani: Urban Diabetic Women's Perception of Healthy Eating Lifestyles

have to be healthy."

Health as multidimensional

All but one participant described their health as healthy, even though one of those was in the hospital at the time of the interview. The other hospitalized participant described her current health status as unhealthy. Participants variously described health drawing on four dimensions: physical, social, mental, and spiritual.

Physical dimension of health. A Fit Body was the primary definer of this dimension indicating symptoms of diabetics were under control and activities of daily life were not problematic. Controlled blood glucose compared to the usual level at a monthly check-up of the hospital was a key indicator. One participant said, "Last night when I had a medical check-up for blood glucose level, it was $166(\mathrm{mg} / \mathrm{dl})$. It is usually $250(\mathrm{mg} /$ dl)." Absence of symptoms meaning no physical complaints like weakness or unclear vision, which the participants had previously experienced after contracting DMT2 were another important indicator: "I do not have complaints of weakness. My eyes, I felt like a blur before, but now I can see clearly." The last indicator was, engaging in activities of daily living. Participants specifically indicated: "I can walk." "Can eat well and can sleep well."

Social dimension of health. Managing one's family or housework for family defined this dimension. Participants reported, "No obstacle to work. I do not have a housemaid at home, so I have to do everything by myself. That's why I have to be healthy. If I am healthy, I can work" This also extended to the health of family. "Healthy is I feel happy. I feel happy when children, grandchildren, and family are healthy."

Mental dimension of health. Comfortable and happy were the two indicators of mental health. This related to the absence of sickness and their ability to conduct daily activities; like the social dimension it included their family. "After I got sick, I felt I am not fit. My activity was hampered. Meaning of health for me is 'Can do activity with comfortable feeling'. 'Healthy is I feel happy. I feel happy when my children, grand children and family are healthy."

Spiritual dimension of health. Participants attributed health as given from God by believing in God. Two participants, Muslim and Christian, who liked to conduct religious activity during their free time described this perception. "I believe that God gives me life. I feel that I depend on God. I always pray and thank to God."

Self-efficacy towards healthy-eating lifestyle Five participants reported that they were confident in managing a healthy-eating lifestyle. "Yes, (I am) confident. I can (practice a healthy-eating lifestyle)".

Participants mentioned four sources which gave them confidence. These were improved or deteriorated health status by prior eating lifestyle, support from God, support from family and support from trusted health professionals.

Improved or deteriorated health status by prior eating lifestyle

Improved health status by controlled eating lifestyle meant that the participant had confidence because she already had successful experience to improve her body weight by practicing a healthy-eating lifestyle. "Yes (confident) because I was already proved by the body weight. My body weight was 53 or 54 kilograms before and it is 51 kilograms now. By controlling myself, I can maintain weight. Deteriorated health status by uncontrolled eating lifestyle indicated that the participant received confidence by her experience of being sick due to uncontrolled eating lifestyle, which motivated her to practice a healthy-eating lifestyle. "Yes I can. I should remember the time when I was sick, it was not good, so I have to practice healthyeating lifestyle. By remembering the time of sick, I can increase my motivation."

\section{Support from God}

Participants reported that they gained confidence by praying and believing in God because God is the one who gave them life and who makes the food to benefit their health. "Praying and believing in God gives me the confidence." "I pray in order that the food becomes healthy. I believe that God gives me life."

Support from family

Participants reported that they gained 
Mayumi Mizutani: Urban Diabetic Women's Perception of Healthy Eating Lifestyles

confidence by receiving support from family members like husband and children. They gave participants encouragement and emotional support to practice a healthyeating lifestyle. "My children call me every morning. Children always ask me 'How about when you eat, your food, and appetite?' I think that I took care of my children previously, but now my children always take care of me."

Support from trusted health professionals Support from trusted health professionals provided participants with confidence by trusting in a doctor who gave them an informational and emotional support for example: "Advice of the doctor. The doctor always tells me if there is a change in blood glucose. I think my relationship with the doctor is very good, I trust in the doctor."

Perceived difficulties towards healthy-eating lifestyle, interpersonal relations, and social situation

Difficulties to practice a healthy-eating lifestyle were embedded in interpersonal relationships and the broader social context. Four indicators supported this subcategory as follows: Difficulty in arranging diet was mentioned along with perceived interpersonal relations because other family member takes the role of food preparation. This meant that it was difficult for the participant to adjust her diet. She described having limited input into meal preparation, as this responsibility normally fell to her daughter. "A nutritionist advised me the kind of food and amount. But I think I cannot do, it is difficult for me. My daughter prepares meals. If I have to arrange my diet, it makes my daughter busier."

Difficulty in refusing offers of food was complexly enmeshed in interpersonal and social interactions. This difficulty was mentioned along with both interpersonal relations like family's invitation to eat together and social situation like social events. Participants would not like to hurt a person who offered them food by refusing to eat, especially when their family invited them to eat together or at events like Pengajian or Lebaran (a feast marking the end of the fasting during Ramadan). "Sometimes I have difficulty when my son or daughter invites me to eat out at a restaurant. I am afraid that my son or daughter will be disappointed if I reject the food at the restaurant." "At Pengajian, we learn Qur'an, listen to religious speeches, and eat: rice, cookie and cake. We take turns, today in one house and another day in another house. They serve different food; it depends on them. Sometimes I eat because I hesitate (to refuse to eat) because of the person who serves the food.

Difficulty in controlling appetite was mentioned especially occurring at social events like wedding parties and Lebaran due to the food, which fascinated them. Many Muslims celebrate Lebaran with family or friends in each other's homes. "In the wedding party, there is food that I really love, I want the food, and I try." "I eat a lot during Lebaran. It is a barrier for me because I can not resist the food."

Difficulty in accessing health care services included difficulty in accessing health care services like monthly medical check-ups due to the expensive medical fee or attending a health seminar due to the distance to the hospital. One participant mentioned that she had to pay fully for the medical fee because her husband had already passed away and she did not have health insurance. Another participant mentioned that she had to travel long distance to go to the hospital, which took one hour by public transportation. "Health is expensive. I should meet a doctor at the hospital once a month and it is expensive. For a doctor, 85,000 rupiah. For medicine, 500,000 rupiah per month." "I am not going there (seminar) because the distance is far."

\section{Discussion}

Reasons to practice healthy eating lifestyle for women with type 2 diabetes in a city of West Java.

Participants practiced healthy eating lifestyle based on their beliefs in their family and in themselves. The term, 'belief' was used because participants practiced healthy eating lifestyle for their family in addition to for their own benefit. This was not consistent with the HPM in which 'benefit' is one of the reasons to practice healthy behaviors. For middle-aged women with DMT2 in the city of West Java, their health meant their 
Mayumi Mizutani: Urban Diabetic Women's Perception of Healthy Eating Lifestyles

own work capacity for their family and they practiced a healthy-eating lifestyle to maintain their health for themselves and for their family. This finding was consistent with the study of Brazilian women with DMT2 (Peres, Franco, Santos, \& Zanetti, 2008).

Increased self-efficacy supported the likelihood of participants in practicing a healthy-eating lifestyle, as supported by the HPM and existing research (Early, Hultz, \& Corbett, 2009 \& McCloskey \& Flenniken, 2010). Participants reported different sources that increased their self-efficacy. Support from God was important to increase their self-efficacy for practicing a healthy-eating lifestyle. This is because Indonesia has a national philosophy of believing in one supreme God' (Atqa, 2010) and beliefs in God are the basis of their perception and life. Support from family and from trusted health professionals was an important source to help participants make changes for a healthy-eating lifestyle and sustain their daily efforts, which was consistent with other research (Hasseler, Heide, \& Indefrey, 2011; McCloskey \& Flenniken, 2010; Miller \& Davis, 2005; Rafique \& Shaikh, 2006; Shultz, Corbett, \& Allen, 2009; \& Wellard, Rennie, \& King, 2008).

Difficulties along with interpersonal relations and social situations were the reasons not to practice healthy-eating lifestyle, which were compatible with the HPM. These findings suggest that it is important for the women to retain social networks with family and friends, which is congruent with a study of Muslim with diabetes in Sweden (Hjelm, et al., 2003). As a background influence, greater food consumption due to the urbanization and economic growth of the city of West Java, might have enabled the women to receive abundant food at social events. Finally, the background influence of low health insurance coverage in the city might have prevented the women from accessing healthcare services. In this city, the possession of health insurance normally depended on the husband's employment status. Thus loss of a husband may have resulted in a constraint in accessing health-care services. As the WHO (2010) noted, inequalities in access to diabetes care within countries can result from various factors, including the method of compensation for diabetics' health-care.

\section{Implications}

The women's healthy-eating lifestyle was based on their beliefs in family. Thus, at hospital-based health education programs, it is necessary to promote women's healthy-eating lifestyle by emphasizing a multidimensional health vision for self and for their family, rather than just focusing on improving their blood glucose or preventing disease.

Family and interpersonal relations were both a source of participants' self-efficacy and related difficulties for a healthy-eating lifestyle. Thus, including family education is crucial, as urged by Early, et al. (2009), Lawton, et al. (2008), and Shultz, et al. (2009). Involving family in the monthly check-ups and health education programs will help the family to understand about the health status of their family member with DMT2.

Trusted health professionals were a source of participants' self-efficacy. Stubbs (2007) explained, a good relationship between the person with diabetes and their healthcare provider is vital to form a working partnership with a good level of trust. Thus, it is necessary for health professionals to build a good relationship with patients with DMT2 at monthly check-ups and at the health education programs.

Support from God was a source of participants' self-efficacy. Therefore, religious gatherings, which are based on their community can be an effective setting to interact with others and share knowledge and experience of health and eating lifestyle.

Social situations like distance from a hospital, no health insurance, or economical constraints can hamper access to health care services. In line with WHO objectives for primary health care, each subdistrict has at least one community health centre in Indonesia. However, the current challenge is to envision a new health system that responds to the changing disease patterns (Heywood \& Harahap, 2009) associated with emerging NCDs. Therefore, the preparation of nurses and midwives at community health centers are crucial to the effective functioning and delivery of primary health care.

Strengths and limitations 
Mayumi Mizutani: Urban Diabetic Women's Perception of Healthy Eating Lifestyles

The strength of this study was that it provided information from the female patient's perspective on perceptions about healthyeating lifestyle in an urban setting of Indonesia and from the perspective of health promotion. Additional studies should include larger and more diverse socioeconomic populations in an extensive area like district level.

This qualitative study used the HPM to focus on motivation of the individual and to provide an understanding from the Indonesian women's perspective. Clearly women's perception seemed to be affected by their surrounding environment. Therefore, further research is needed to understand more about the women's environment including the health system, community, and society.

\section{Conclusion}

West Java, like all of Indonesia, is experiencing an emergence of non-communicable diseases related to lifestyle changes related to globalization and urbanization. Diabetes is on the rise and is not well controlled. The reasons for practicing a healthy-eating lifestyle for middle-aged women with DMT2 in a city of West Java were a complex mix of personal, interpersonal, and social factors. These findings suggest that women with DMT2 in the city of West Java need health care providers and family to support them with the reasons to practice a healthyeating lifestyle. University), Tokyo, Japan. This study was supported by a grant from the program of "Development of novice researchers who will contribute evidencebased nursing globally for the promotion of people-centered care", St. Luke's College of Nursing. These findings suggest that women with type 2 diabetes in Indonesia need to be supported with the reasons to practice a healthy-eating lifestyle.

\section{References}

Atqa, M. (2010). Religious expression in Indonesia-A sociological study of Ahmadiyya movement. OIDA [Ontario International Development Agency] International Journal of Sustainable Development, 1(6), 19-31.
Badan Pusat Statistik Kabupaten Bandung (2009). Kabupaten Bandung dalam angka tahun 2009. Retrieved from http:// bapeda.bandungkab.go.id/index 2 . $\mathrm{php}$ ?option $=\mathrm{com}$ doc man\&task $=\mathrm{doc}$ view\&gid=79\&Itemid $=314$.

Bandura, A. (1986). Social foundations of thought and action: A social cognitive theory. New Jersey: Prentice Hall.

Brown, L. (2001). Redesigning cities for people: Urbanization and obesity, in $L$. brown, eco-economy: Building an economy for the earth. Retrieved from http://www. earth-policy.org/books/eco/eech9_ss4.

Departemen Kesehatan Republik Indonesia (2009). Profil kesehatan Indonesia 2008. Retrieved from http://www.depkes. go.id/downloads/publikasi/Profil\%20 Kesehatan\%20Indonesia\%202008.pdf.

Dewi, F. S. T. (2010). 'Maintaining balance and harmony': Javanese perceptions of health and cardiovascular disease. Global Health Action, 3, 1-10.

Dinas Kesehatan Provinsi Jawa Barat (2008). Table profil kesehatan provinsi Jawa Barat tahun 2007. Retrieved from http://www. depkes.go.id/downloads/profil/prov\%20 jabar\%202007.pdf.

Early, K. B., Shultz, J. A., \& Corbett, C. (2009). Assessing diabetes dietary goals and self-management based on in-depth interviews with Latino and Caucasian clients with type 2 diabetes. Journal of Transcultural Nursing, 20(4), 371-381.

Food and Agriculture Organization of the United Nations (2010). FAOSTAT. Retrieved from http://faostat.fao.org/.

Hasseler, M. K., Heide, M., \& Indefrey, S. (2011). Resources for and barriers to effective diabetes care management-experiences and perspectives of people with type 2 diabetes. Journal of Public Health, 19(1), 65-71.

Hawkes, C. (2006). Uneven dietary development: linking the policies and 
Mayumi Mizutani: Urban Diabetic Women's Perception of Healthy Eating Lifestyles

processes of globalization with the nutrition transition, obesity and diet-related chronic diseases. Globalization and Health, 2, 4. doi:10.1186/1744-8603-24.

Heywood, P., \& Harahap, N. P. (2009). Health facilities at the district level in Indonesia. Australia and New Zealand Health Policy, 6, 13.

Hjelm, K., Bard, K., Nyberg, P., \& Apelqvist, J. (2003). Religious and cultural distance in beliefs about health and illness in women with diabetes mellitus of different origin living in Sweden. International Journal of Nursing Studies, 40(6), 627-643.

Ho, A. Y. K., Berggren, I., \& DahlborgLyckhage, E. (2010). Diabetes empowerment related to Pender's health promotion model: A meta-synthesis. Nursing and Health Sciences, 12(2), 259-267.

Lawton, J., Ahmad, N., Hanna, L., Douglas, M., Bains, H., \& Hallowell, N. (2008). 'We should change ourselves, but we can't': Accounts of food and eating practices amongst British Pakistanis and Indians with type 2 diabetes. Ethnicity \& Health, 13(4), 305-319.

McCloskey, J., \& Flenniken, D. (2010). Overcoming cultural barriers to diabetes control: A qualitative study of southwestern New Mexico Hispanics. Journal of Cultural Diversity, 17(3), 110-115.

Miller, C. K., \& Davis, M. S. (2005). The influential role of social support in diabetes management. Topics in Clinical Nutrition, 20(2), 157-165.

Nordisk, N. (2013). Where economics and health meet: changing diabetes in Indonesia. Retrieved from http://www.novonordisk. com/images/Sustainability/PDFs/Blueprintfor-change-Ind onesia--52383_Korr19.pdf.

Pemerintah Kota Bandung. (2010). Informasi laporan penyelenggaraan pemerintahan daerah Kota Bandung tahun 2010. Retrieved from http://www.bandung.go.id/images/ download/ILPPD_2010.pdf.
Pender, N. J., Murdaugh, C. L., \& Parsons, M. A. (2011). Health promotion in nursing practice (6th Ed.). New Jersey: Pearson Education.

Peres, D. S., Franco, L. J., Santos, M. A., \& Zanetti, M. L. (2008). Social representations of low-income diabetic women according to the health-disease process. Revista LatinoAmericana De Enfermagem (RLAE), 16(3), 389-395.

Rada, N., \& Regmi,A. (2010). Trade and food security implications from the Indonesian agricultural experience. Retrieved from http://www.ers.usda.gov/Publications/ WRS1001/WRS1001.pdf.

Rafique, G., \& Shaikh, F. (2006). Identifying needs and barriers to diabetes education in patients with diabetes. Journal of the Pakistan Medical Association, 56(8), 347-352.

Shultz, J. A., Corbett, C. F., \& Allen, C. B. (2009). Slavic women's understanding of diabetes dietary self-management and reported dietary behaviors. Journal of Immigrant and Minority Health/ Center for Minority Public Health, 11(5), 400-405.

Soewondo, P., Soegondo, S., Suastiki, K., Pranoto, A., Soeatmadji, D. \& Tjokroprawiro, A. (2010). The Diab Care Asia 2008 study outcomes on control and complications of type 2 diabetic patients in Indonesia. Medical Journal of Indonesia, 19(4). Retrieved from http://mji.ui.ac.id/journal/index.php/mji/ article/view/412/404.

Stubbs, M. (2007). Empowerment in middleaged people with diabetes: The importance of working relationships. Journal of Diabetes Nursing, 11(5), 190-195.

Wellard, S. J., Rennie, S., \& King, R. (2008). Perceptions of people with type 2 diabetes about self-management and the efficacy of community based services. Contemporary Nurse: A Journal for the Australian Nursing Profession, 29(2), 218-226.

Wild, S. (2004). Global prevalence of diabetes. Diabetes Care, 27(5), 1047-1053. 
Mayumi Mizutani: Urban Diabetic Women's Perception of Healthy Eating Lifestyles

World Health Organization. (2004). Global strategy on diet, physical activity and health. Geneva: World Health Organization.

WorldHealthOrganization.(2005).Preventing chronic diseases: A vital investment. Geneva: World Health Organization.

World Health Organization. (2010). Equity, social determinants and public health programmes. Geneva: World Health Organization.

World Health Organization. (2011a). Global status report on noncommunicable diseases 2010. Geneva: World Health Organization.

World Health Organization. (2011b). Death estimates for 2008 by cause for World Health Organization member states. Retrieved from http://www.who.int/gho/mortality burden disease/global_burden_disease_death_est imates_sex_2008.xls.

Yin, R. K. (2008). Case study research: design and methods. (4th ed.). Newbury Park CA: Sage. 